
Digitized by the Internet Archive in 2011 with funding from University of Toronto 



\title{
CONTRIBUTIONS
}

OF THE

ROYAL ONTARIO MUSEUM OF ZOOLOGY AND PALAEONTOLOGY

No. 37

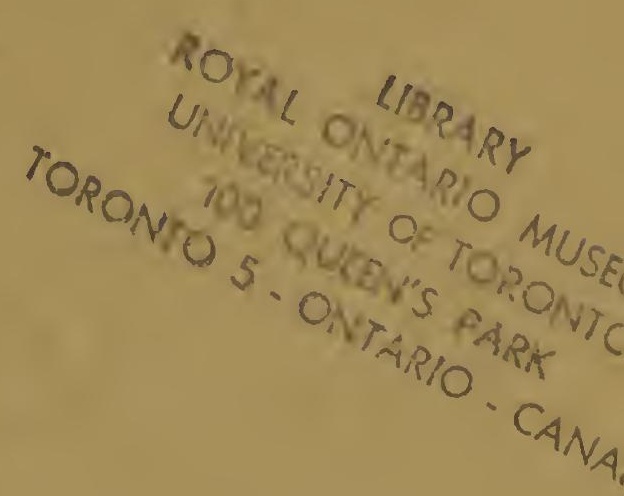

\section{NOTES ON THE EASTERN DISTRIBUTION OF EUTAMIAS MINIMUS}

\author{
By \\ Randolph L. Peterson
}

TORONTO

DECEMBER 31, 1953 



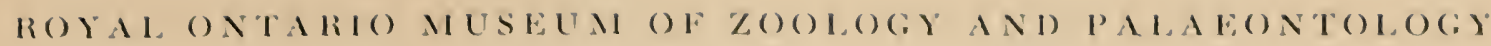
(:ONTRIBUTHON NO. B

\section{NOTES ON THE EASTERN DISTRIBUTION OF EUTAMIAS MINIMUS}

by

\section{Raniolph L. Peterson}

IN HIS REvision of the American chipmunks, Howell (1929) referred specimens from the northeastern portion of Ontario to E. M. borealis. In his definition of the eastem limits of the range he states (p. 54) ... "east to the Mattaganni River and Lake Nipissing, eastern Ontario." He gives no proof, insofar as collected specimens are concerned, for extending the range southeast as far as Lake Nipissing; the nearest specimens, which he records, were from Ridout, approximately 150 miles away. Undoubtedly he based his map on data supplied by Miller (1897) who had collected a specimen at North Bay, and who, at the same time, clearly stated that it was the most easterly point where this form had been collected. His definition of the eastern limits as being along the Mattagami River, on which he bases his distribution map (p. 37) is difficult to understand because he examined specimens from Iroquois Falls, which is located at least 3.5 miles east of the defined area, and from Lake Abitibi, which is approximately 70 miles northeast of the range which he has defined.

When Anderson and Rand (1944) reported on the Canadian subspecies of Eutamias minimus they described E. m. hudsonius from northern Manitoba and they concluded that the eastern Ontario form should be regarded as $E$. $m$. neglectus. They defined the range as "from southeastern Manitoba across Ontario probably to Lake Abitibi, north at least to Lake Seul and Kapuskasing, and southward into northern Michigan, Wisconsin and northeastern Minnesota; intergrading with borealis in southern Manitoba and probably with hudsonius in northern Ontario." The southeastern limit of range was apparently completely ignored.

It is the writer's conclusion that a more thorough study of Eutamias minimus in Ontario and Manitoha must be carried out before the ranges of the geographic races can be defined.

Cross and Dymond ( 1929$)$ had no record of Eulamias from localities south of North Bay, although Saunders (1929) reported a specimen 
from Noganosh Lake, Parry Sound District (sce fig. 1). Saunders collected specimens along the French River (one in 1926 and two in 1928). These, as well as the Noganosh Lake specimen are now in the collections of the Royal Ontario Museum of Zoology and Palaeontology. Between the years 1929 and 1933 fifteen specimens were taken near Frank's Bay on the south side of Lake Nipissing. Eutamias was not reported from Algonquin Park until a single specimen was taken by D. A. MacLulich in Lister Township in 1931 in the north central part of the Park. With the addition of five specimens collected by C. H. D. Clarke in 1932 and 1933 the known range was extended to Long Lake in the northwestern portion of the Park. In 19:38 Baillie (1939) collected a specimen at Pickerel Lake, which is located approximately 7 miles east of Burks Falls, thus extending the known range south in the Parry Sound District. In 1946 the author collected three specimens at Longbow Lake, thus extending the southern limits in Algonquin Park. In 1947 a specimen was collected still further southeast at Cache Lake, in Algonquin Park.

The northem distributional limits are rather vague. Authentic records, based on specimens in the collection of the Royal Ontario Museum of Zoology and Palaeontology, are shown in Fig. 1. The series of five specimens collected two miles west of Fort Albany is the first indication that the range of Eutamias extends as far north as James Bay. Further west, in Manitoba, specimens have been taken as far north as Herchmer (Anderson and Rand, 1943).

During the summer of 1953 specimens were collected at the following localities in western Quebec: 6 miles north of Authier Nord and 5 miles east of Duparquer, both in Abitibi Ouest County; 11 miles north of Guerin, Rouyn-Noranda County. These specimens constitute the first known records of Eutamias for the Province of Quebec.

Although collections of mammals have been made by the author and others on the Great Lakes islands (Isle Royale, St. Ignace, Simpson, Slate Islands and Manitoulin) no specimens of Eutamias were obtained, which would seem to indicate that it is absent from these islands. This is an interesting aspect in the general distribution of the genus.

From the data which have been presented above, it would appear that Eutamias has extended its range, within recent years, in the region south of Lake Nipissing in Ontario.

It is possible that similar range extensions have taken place in northem Ontario and Quebec, but insufficient data are available to arrive at such a conclusion. 


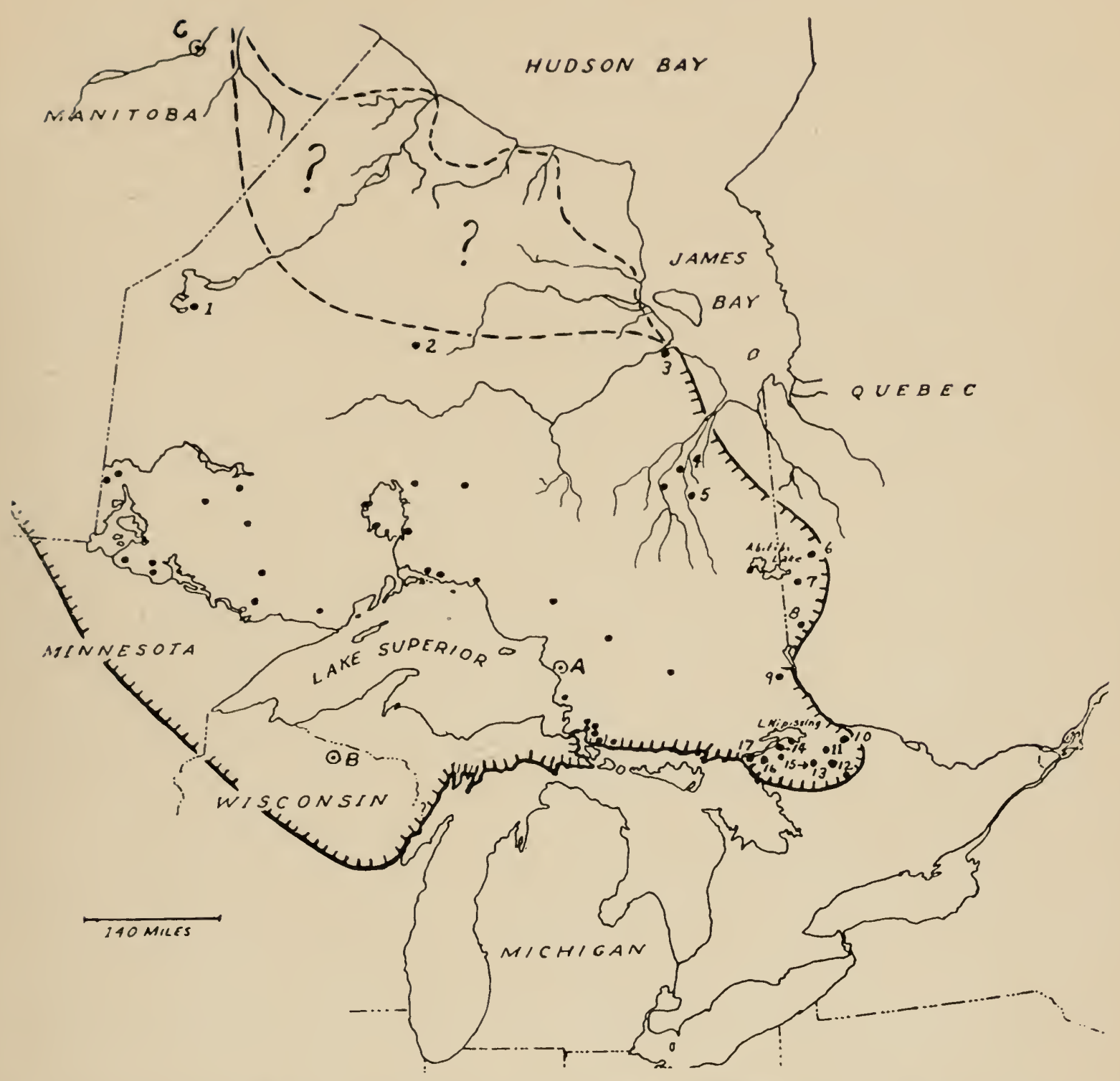

Fic: 1. Map showing the distribution of Eutamias minimus east of Manitoba. Type localities: A. E. m. neglectus; B. E. m. jacksoni; C, E. m. huudsonius. Marginal records (specimens in the Royal Ontario Museun of Zoology and Palaeontology): 1. Favourable Lake; 2. Lake Attawapiskat; 3. 2 mi. West Fort Albany; 4. Coral Rapicls; 5. Frascrelale; 6. 6 mi. N. Authier Nord; 7. 5 mi. E. Duparguer; 8. 11 mi. N. Guerin; 9. Temagani; 10. Lister Twp., Algonquin Park; 11. Long Lake, Algonguin Park; 12. Carche Lake, Algonquin Park; 13. Longhow Lake, Algonquin Park; 14. Frank's Baly, Lake Nipissing; 15. Pickerel Like; 16. Noganosh Lake; 17. French River. 


\section{ACKNOWLEDGIMENT}

The anthor wishes to acknowledge the financial assistance given to him by the Research Comncil of Ontario which permitted him to send a special collecting expedition to various parts of eastern Ontario and westem Quebec in 1953. The data obtained as a result of this expedition, greatly assisted the author in determining the eastem limits of the geographical distribution of Eutamias minimus in Canada.

\section{Literature Cite1)}

Anderson, R. M. ANi) A. L. Ranis

1944. Notes on chipmunks of the genus Eutamis in Canada. Cans. Field-Nat., vol. 57 , nos. 7 and 8 , pp. 133-1:3.5.

BAILLIE, JANES L., J

1939. The northern chipmunk in Parry Somnd District, Ontario. Cin. Fiald-Nat., vol. 53, no. 4, P. 59

Cross, E. C. Anis J. R. Dymond

1939. The mammals of Ontario. Roy. Ont. Mus. Zool., Handbook no. 1, pp. 1-5.5. HOWELL, A. H.

1929. Revision of the American chipmunks. N. Am. Famma no. 52, pp. 1-145.

Millek, G. S., J11.

1897. Notes on the mammals of Ontario. Proc. Boston Soc. Nit. Hist., vol. 28, no. 1, pp. 1-44.

SAUNiders, IV.E.

1929. Notes on the white-lipped shrew and other species in the Parry Sound District. Can. Fisld-Nat., vol. 43, no. 9, pp. $207-8$. 



$$
512
$$






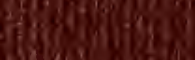

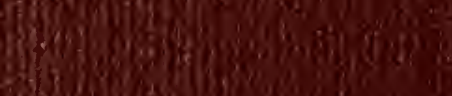

Wing

4.

6)

aglo

(6)

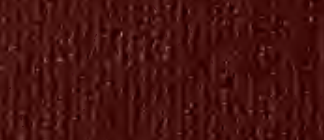

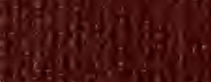

(1)

$(9)^{-3}$

totsesis

o

ing

(1)

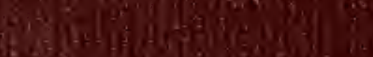

tivising

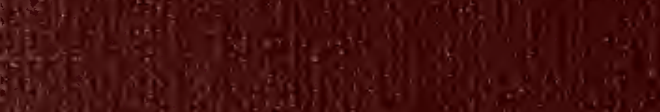

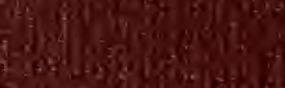

